\begin{tabular}{|c|c|c|}
\hline & Int.J.Curr.Microbiol.App.Sci (2021) 10(12): 198-205 & \\
\hline & $\begin{array}{l}\text { International Journal of Current Microbiology and Applied Sciences } \\
\text { ISSN: 2319-7706 Volume } 10 \text { Number } \mathbf{1 2} \mathbf{( 2 0 2 1 )} \\
\text { Journal homepage: http://www.ijcmas.com }\end{array}$ & $\$ 0$ \\
\hline $\begin{array}{l}\text { EXCELLENT } \\
\text { PUBLISHERS }\end{array}$ & & \\
\hline
\end{tabular}

\title{
Macro and Micro Nutrient Status of Instructional Farm, College of Agriculture and Research Station Raipur, District Raipur, Chhattisgarh
}

\author{
Amit Singh Sengar*, K. Tedia, D. Khalkho, Gourav Jatav, \\ Manoj Kumar Tarar and Ravishankar Dadsena \\ Department of Agriculture, IGKV, Raipur, Chhattisgarh-492001, India \\ *Corresponding author
}

\section{Keywords}

\section{Chemical}

properties, available nutrients, DTPAextractable, macro nutrients, micro nutrients

\section{Article Info}

Received: 10 November 2021 Accepted: 04 December 2021 Available Online: 10 December 2021

\section{A B S T R A C T}

The current study was conducted at Instructional farm of IGKV, Raipur district, Chhattisgarh, 2021 to assess the macro and micro nutrient status of the soil. A random sampling procedure was used to gather surface $(0-15 \mathrm{~cm})$ soil samples, yielding a total of 126 samples for analysis of soil chemical characteristics. Soil response $(\mathrm{pH})$, electrical conductivity (EC), organic carbon (OC), available macro-nutrients (e.g. N, P, K, S), \& DTPA-extractable micro-nutrients (e.g. Iron, Manganese, Copper, Zinc, and hot water extractable Boron) were all tested in the soil samples. The soil $\mathrm{pH}$ of the study region ranged from 6.51 to 7.78 . It indicates that the $\mathrm{pH}$ of the soil is in the neutral to slightly alkaline range. The electrical conductivity found to be fall under the normal category with average value of $0.25 \mathrm{dS} / \mathrm{m}$. Organic carbon in this soil was found to be around $0.38 \%$. Available Nitrogen content was found between 163 to 278 $\mathrm{kg} \mathrm{ha}^{-1}$. The available Phosphorus content varied from 2.6 to $28.9 \mathrm{~kg} \mathrm{ha}^{-1}$. Available Potassium content ranged from 201.23 to $443.96 \mathrm{~kg} \mathrm{ha}^{-1}$. The available Sulphur content ranged from 9.32 to $36.67 \mathrm{~kg} \mathrm{ha}^{-1}$. DTPA extractable micronutrient anions content was found that the Iron content varied from 4.1 to $31.4 \mathrm{mg} \mathrm{kg}^{-1}$. The Manganese content ranged between 2.2 to $22 \mathrm{mg} \mathrm{kg}^{-1}$. Copper content varied from 0.4 to $1.7 \mathrm{mg} \mathrm{kg}^{-1}$. Zinc content ranged from 0.4 to $2.3 \mathrm{mg} \mathrm{kg}^{-1}$. Hot- water extractable Boron content found to be between 0.1 to $0.8 \mathrm{mg} \mathrm{kg}^{-1}$.

\section{Introduction}

Soil fertility is one of the important factors controlling yields of the crops. Soil characterization in relation to evaluation of fertility status of the soils of an area or region is an important aspect in context of sustainable agriculture production. Because of imbalanced and inadequate fertilizer use coupled with low efficiency of other inputs, the response (production) efficiency of chemical fertilizer nutrients has declined tremendously under intensive agriculture in recent years. Balanced use of organics, fertilizers and biofertilizers plays an important role to maintain soil fertility in long run. The availability of macro 
and micronutrients to plants is influenced by several soil characteristics. Land use pattern also plays a vital role in governing the nutrient dynamics and fertility of soils (Venkatesh et al., 2003). Similarly, different cropping systems are suitable for different soil groups as regards to production and productivity. Texture, structure, color, etc are important physical parameters of the soil. Similarly the soil reaction $(\mathrm{pH}), \mathrm{EC}$, organic matter, macro and micro-nutrients, etc are important chemical parameters of the soil. These soil properties play an important role in soil fertility and these are determined after soil testing (Brady and Weil, 2004). Soil fertility is the inherent capacity of the soil to supply nutrients to plants in adequate amounts and in adequate proportions. Soil productivity is the capacity of a soil to produce a certain yield of agricultural crops or other plants using a defined set of management practice. Soil fertility and productivity are the key factors for food production and soil quality is just as important in the context of soil degradation caused by many factors. All productive soils can be fertile, but all fertile soils cannot be productive due to some factors of influence, such as water logging, salinity or alkalinity conditions, unfavorable weather conditions etc.

\section{Materials and Methods}

The study area was carried out at Instructional Farm, College of Agriculture and Research Station Raipur, District Raipur, Chhattisgarh is located at latitude $22^{\circ} 33 ' \mathrm{~N}$ and $21^{\circ} 14 ' \mathrm{~N}$, and the longitudes of $82^{\circ} 6^{\prime} \mathrm{E}$ and $81^{\circ} 38^{\prime} \mathrm{E}$ with an altitude is 280 M.A.S.L. The farm has a total area of 71.24 acres, which is mainly Vertisols and Inceptisols soils.

\section{Sample collection}

Surface soil samples $(0-15 \mathrm{~cm}$ depth) were obtained from several instructional, horticultural, and KVK farms of IGKV, Raipur based on the handheld GPS device. Total of 126 soil samples were obtained from the farm area for examination of soil chemical characteristics. The collected soil samples were air dried after grinding with wooden pestle and mortar, than sieved through $2 \mathrm{~mm}$ sieve, labelled and stored.

\section{Laboratory analysis}

The collected soil samples were analyzed at laboratory of soil science department. The different soil parameters tested as well as method adopted to analyze is shown on the table below

\section{Results and Discussion}

\section{Soil reaction}

The soil $\mathrm{pH}$ of the study region ranged from 6.51 to 7.78 , it indicates that the $\mathrm{pH}$ of the soil is in the neutral to slightly alkaline range. Majority of soil samples $(94.44 \%)$ had a neutral soil reaction, while the remaining $5.56 \%$ had a slightly alkaline reaction (Table 1). It might be due to barren nature of the field with Vertisols dominant soil (Mandal et al., 2018).

\section{Electrical conductivity}

The electrical conductivity of the soil water suspension ranged from 0.15 to $0.52 \mathrm{dS} / \mathrm{m}$ in soil of study area with a mean value of 0.25 $\mathrm{dS} / \mathrm{m}$.

Most of the $100 \%$ collected soil samples fall under normal E.C. $(<1.0 \mathrm{dS} / \mathrm{m})$ category (Table 2). It indicated that there is no soil limitation for crop production from soluble salt content in soil. Similar results were also reported by like Balakrishna et al., 2017 in Palari Block soil and Dameswar et al., 2017 in Kasdol Block soil in Chhattisgarh. 


\section{Organic carbon}

Organic Carbon content in study area ranged from 0.15 to $0.63 \%$ with a mean value of $0.38 \%$. From all collected soil samples 85.71 $\%$ of the 126 samples gathered had a poor rating, while the remaining $14.29 \%$ had a medium fertility category (Table 3 ). It may be ascribed due to low input of FYM and crop residues as well as rapid rate of decomposition due to high temperature (Sathish et al., 2018).

\section{Available nitrogen}

Available $\mathrm{N}$ content in soil of study area ranged from 163 to $278 \mathrm{~kg} \mathrm{ha}^{-1}$ with mean value of $202.39 \mathrm{~kg} \mathrm{ha}^{-1}$. It has been revealed that $100 \%$ of the study area was deficient in available $\mathrm{N}$ (Table 4). It may be ascribed to the nitrogen is lost through various mechanisms like ammonia volatilization, nitrification, chemical and microbial fixation, leaching, runoff and these soils had a very low content of organic carbon. (vaisnow et al., 2010)

\section{Available phosphorus}

Available P content in the study area found to be varied from 2.60 to $28.9 \mathrm{~kg} \mathrm{ha}^{-1}$ with average content of $16.21 \mathrm{~kg} \mathrm{ha}^{-1}$. It was revealed that $24 \%$ samples fall under deficient category, $72 \%$ samples in medium range and $4 \%$ falls under high range of available $\mathrm{P}$ content (Table 5). It might be due to the mostly affected by past fertilization, $\mathrm{pH}$, Organic matter content, texture various soil management and agronomic practices (Balakrishna et al., 2017).

\section{Available potassium}

Soil available K status ranged from 201.23 to $443.96 \mathrm{~kg} \mathrm{ha}^{-1}$ with mean value of $296.42 \mathrm{~kg}$ $\mathrm{ha}^{-1}$. As $82 \%$ samples falls into the medium category and the remaining $18 \%$ samples fall into the high category (Table 6), indicating no $\mathrm{K}$ deficient area within the study area. These findings were similar to those of Balakrishna (2017) in the Palari block.

\section{Available sulphur}

Available $\mathrm{S}$ status was found to be ranged between 9.32 to $36.67 \mathrm{~kg} \mathrm{ha}^{-1}$ with a mean content of $22.16 \mathrm{~kg} \mathrm{ha}{ }^{-1}$. Also it was found that out of all collected samples $56.34 \%$ were classified as low, $39.68 \%$ as medium, and the remaining $3.98 \%$ as sufficient (Table 7 ).

\section{Available boron}

Hot water extractable B content in the study area found to be ranged between 0.10 to 0.80 $\mathrm{mg} \mathrm{kg}{ }^{-1}$ with a mean value of $0.28 \mathrm{mg} \mathrm{kg}^{-1}$. Out of $100 \%$ samples collected $88.88 \%$ samples reported in deficient and rest $11.12 \%$ samples in sufficient B content category (Table 8).

\section{DTPA extractable micronutrients}

Available Fe content in the study area found to be ranging from 4.1 to $31.4 \mathrm{mg} \mathrm{kg}^{-1}$ with mean value of $10.66 \mathrm{mg} \mathrm{kg}^{-1}$. The majority of soil samples were determined to be sufficient $(61.90 \%)$, with the remaining $37.30 \%$ in the high range and $0.8 \%$ in the poor deficient range (Table 9). 
Table.1

\begin{tabular}{|c|c|c|}
\hline S.N. & Parameters & Methods \\
\hline $\mathbf{1}$ & Soil pH & Glass Electrode $\mathrm{pH}$ Meter (Piper, 1967) \\
\hline $\mathbf{2}$ & EC & Conductivity Bridge (Black, 1965) \\
\hline $\mathbf{3}$ & Organic matter & Walkely and Black (1934) \\
\hline $\mathbf{4}$ & Available N & Alkaline permanganate method (Subbiah and Asija, 1956) \\
\hline $\mathbf{5}$ & Available P & Olsen's method (Olsen et al., 1954) \\
\hline $\mathbf{6}$ & Available K & Ammonium acetate extract method (Jackson,1967) \\
\hline $\mathbf{7}$ & Available S & $\mathrm{CaCl}_{2}$-Extractable method (Williams and Steinbergs, 1969) \\
\hline $\mathbf{8}$ & Available B & Hot water soluble (Berger and Truog, (1977) \\
\hline $\mathbf{9}$ & Available Fe & DTPA extraction method (Lindsay and Norvell, 1978) \\
\hline $\mathbf{1 0}$ & Available $\mathrm{Zn}$ & DTPA extraction method (Lindsay and Norvell, 1978) \\
\hline $\mathbf{1 1}$ & Available Cu & DTPA extraction method (Lindsay and Norvell, 1978) \\
\hline $\mathbf{1 2}$ & Available $\mathrm{Mn}$ & DTPA extraction method (Lindsay and Norvell, 1978) \\
\hline
\end{tabular}

Table.2 Distribution of Soil Samples under different $\mathrm{pH}$ rating

\begin{tabular}{|c|c|c|c|}
\hline Classes & Range & No. of Samples & \% of Samples \\
\hline Strongly acidic & $<4.5$ & 0 & 0 \\
\hline Moderately acidic & $4.5-5.5$ & 0 & 0 \\
\hline Slightly acidic & $5.5-6.5$ & 0 & 0 \\
\hline Neutral & $6.5-7.5$ & 119 & 94.44 \\
\hline Slightly alkaline & $7.5-8.5$ & 7 & 5.56 \\
\hline Moderately alkaline & $8.5-9.5$ & 0 & 0 \\
\hline Strongly alkaline & $>9.5$ & 0 & 0 \\
\hline
\end{tabular}

Table.3 Distribution of Soil Samples under different E.C. rating

\begin{tabular}{|c|c|c|c|}
\hline Classes & Range (dS/m) & No. of Samples & \% of Samples \\
\hline Low & $<1$ & 126 & 100 \\
\hline Medium & $1.0-2.0$ & 0 & 0 \\
\hline High & $2.0-3.0$ & 0 & 0 \\
\hline Very High & $>3.0$ & 0 & 0 \\
\hline
\end{tabular}

Table.4 Distribution of Soil Samples under different Organic Carbon rating

\begin{tabular}{|c|c|c|c|}
\hline Classes & Range (\%) & No. of Samples & \% of Samples \\
\hline Low & $<0.5$ & 108 & 85.71 \\
\hline Medium & $0.5-0.75$ & 18 & 14.29 \\
\hline High & $>0.75$ & 0 & 0 \\
\hline
\end{tabular}


Table.5 Distribution of Soil Samples under different Nitrogen rating

\begin{tabular}{|c|c|c|c|}
\hline Classes & Range (kg/ha) & No. of Samples & \% of Samples \\
\hline Low & $<280$ & 126 & 100 \\
\hline Medium & $280-560$ & 0 & 0 \\
\hline High & $>560$ & 0 & 0 \\
\hline
\end{tabular}

Table.6 Distribution of Soil Samples under different Phosphorus rating

\begin{tabular}{|c|c|c|c|}
\hline Classes & Range (kg/ha) & No. of Samples & \% of Samples \\
\hline Low & $<12.5$ & 30 & 23.80 \\
\hline Medium & $12.5-25$ & 91 & 72.22 \\
\hline High & $>25$ & 5 & 3.98 \\
\hline
\end{tabular}

Table.7 Distribution of Soil Samples under different Potassium rating

\begin{tabular}{|c|c|c|c|}
\hline Classes & Range $\left(\mathbf{k g ~ h a}^{-\mathbf{1}}\right)$ & No. of Samples & \% of Samples \\
\hline Low & $<135$ & 0 & 0 \\
\hline Medium & $135-335$ & 103 & 81.75 \\
\hline High & $>335$ & 23 & 18.25 \\
\hline
\end{tabular}

Table.8 Distribution of Soil Samples under different Sulphur rating

\begin{tabular}{|c|c|c|c|}
\hline Classes & Range $\left(\mathbf{k g ~ h a}^{-\mathbf{1}}\right)$ & No. of Samples & \% of Samples \\
\hline Low & $<22.5$ & 71 & 56.34 \\
\hline Medium & $22.5-35$ & 50 & 39.68 \\
\hline High & $>35$ & 5 & 3.98 \\
\hline
\end{tabular}

Table.9 Distribution of Soil Samples under different Boron rating

\begin{tabular}{|c|c|c|c|}
\hline Classes & Range $\left(\mathbf{m g ~ k g}^{-\mathbf{1}}\right)$ & No. of Samples & \% of Samples \\
\hline Deficient & $<0.5$ & 112 & 88.88 \\
\hline Sufficient & $0.5-1.0$ & 14 & 11.12 \\
\hline High & $>1.0$ & 0 & 0 \\
\hline
\end{tabular}

Table.10 Distribution of Soil Samples under different Iron rating

\begin{tabular}{|c|c|c|c|}
\hline Classes & Range $\left(\mathbf{m g ~ k g}^{-\mathbf{1}}\right)$ & No. of Samples & \% of Samples \\
\hline Deficient & $<4.5$ & 1 & 0.8 \\
\hline Sufficient & $4.5-9.0$ & 78 & 61.90 \\
\hline High & $>9.0$ & 47 & 37.30 \\
\hline
\end{tabular}


Table.11 Distribution of Soil Samples under different Copper rating

\begin{tabular}{|c|c|c|c|}
\hline Classes & Range $\left(\mathbf{m g ~ k g}^{-\mathbf{1}}\right)$ & No. of Samples & \% of Samples \\
\hline Deficient & $<0.2$ & 0 & 0 \\
\hline Sufficient & $0.2-0.4$ & 2 & 1.59 \\
\hline High & $>0.4$ & 124 & 98.41 \\
\hline
\end{tabular}

Table.12 Distribution of Soil Samples under different Manganese rating

\begin{tabular}{|c|c|c|c|}
\hline Classes & Range $\left(\mathbf{m g ~ k g}^{-\mathbf{1}}\right)$ & No. of Samples & \% of Samples \\
\hline Deficient & $<3.5$ & 6 & 4.77 \\
\hline Sufficient & $3.5-7.0$ & 72 & 57.14 \\
\hline High & $>7.0$ & 48 & 38.09 \\
\hline
\end{tabular}

Table.13 Distribution of Soil Samples under different Zinc rating

\begin{tabular}{|c|c|c|c|}
\hline Classes & Range $\left(\mathbf{m g ~ k g}^{-\mathbf{1}}\right)$ & No. of Samples & \% of Samples \\
\hline Deficient & $<0.6$ & 0 & 0 \\
\hline Sufficient & $0.6-1.2$ & 94 & 74.60 \\
\hline High & $>1.2$ & 32 & 25.40 \\
\hline
\end{tabular}

Available Mn content found to be within 2.2 to $22 \mathrm{mg} \mathrm{kg}^{-1}$ with a mean value of $7.09 \mathrm{mg}$ $\mathrm{kg}^{-1}$ of soil in the study area. Out of 126 samples collected, $57.14 \%$ fall into the sufficient fertility category, while the remaining $38.09 \%$ and $4.77 \%$ fall into the high and insufficient Mn fertility categories, respectively (Table 10).

Available $\mathrm{Cu}$ content in study area found to be ranges from 0.4 to $1.7 \mathrm{mg} \mathrm{kg}^{-1}$ with a mean value of $0.92 \mathrm{mg} \mathrm{kg}^{-1}$. There were no samples in the low rating category among the 126 samples collected, $1.59 \%$ samples were sufficient, and the remaining $98.41 \%$ samples were in the high rating category (Table 11).

Available $\mathrm{Zn}$ content in study area found to be ranges from 0.40 to $2.30 \mathrm{mg} \mathrm{kg}^{-1}$ with a mean value of $1.04 \mathrm{mg} \mathrm{kg}^{-1}$. Also it was found that $74.60 \%$ samples were in sufficient and $25.40 \%$ samples in high fertility category (Table 12). In case of available $\mathrm{Cu}, \mathrm{Fe}$ and Mn, $100 \%$ samples were under high level. Similar results were reported by Dixit (2014) and Singh et al., (2014). The soil of the area was found to be neutral to slightly alkaline in reaction with electrical conductivity less than $1 \mathrm{dS} / \mathrm{m}$ of KVK, horticulture and instructional farms, IGKV, Raipur. Organic carbon levels in soil were determined to be low to medium. Macro nutrient analysis results shows that the soils were low in available nitrogen and sulphur content. The status of available phosphorus and potassium in soil were found to be in medium range. In case of micronutrients, zinc and manganese were found to be in sufficient condition but boron content of the soil was low. Iron and copper status in soils of the farms were high.

\section{References}

Iftikar, W., Chattopadhayaya, G. N., Majumdar, K. and Sulewski, G. D. (2010) Use of village-level soil fertility maps as a fertilizer decision support tool in the red and lateritic soil zone of India. Better Crops 94, 10-12.

Balakrishna. 2017. Evaluation of Soil Fertility 
Status in Soils of Palari Block Under Balodabazar District of Chhattisgarh, M.Sc. (Ag.) Thesis, I.G.K.V. Raipur (Chhattisgarh), Pp.39-80.

Singh, G., Kumar, B. and Shasikant (2019) Soil Fertility Mapping Using Remote Sensing and GIS in NSP Farms of ND University of Agriculture and Technology, Kumarganj, Faizabad, Uttar Pradesh, India. ISSN: 2319-7706 Special Issue-7 pp. 1394-1402

Black, C. A. 1965. Method of soil analysis American Agro Inc., Madison, USA: 131.

Brady, N. C. and Weil, R. R. 2002. The nature and properties of soils. 13th edition. Pearson Education, New Jersey.

Dixit, H. C. (2014) Status of sulphur and zinc in soil of Lalitpur district of Burdelkhand region, Uttar Pradesh. Annals of Plant and Soil Research 16 (3): 273-274

Desavathu, R. N., Nadipena, A. R. and Peddada, J. R. 2018. Assessment of soil fertility status in Paderu Mandal, Visakhapatnam district of Andhra Pradesh through Geospatial techniques. Egyptian Journal of Remote Sensing and Space Sciences, 21: 73-81.

Flores-Magdaleno, H., Mancilla-Villa, O. R., Mejia-Saenz, E., Olmedo-Bolantilde, M. D. C. and Bautista-Olivas, A. L. 2011. Heavy metals in agricultural soils and Irrigation wastewater of Mixquiahuala, Hidalgo, Mexico. African Journal of Agriculture Research, 6(24): 5505-5511.

Lindsay, W. L. \& Norvell, W. A. 1978.

Development of DTPA soil test for zinc, iron, manganese and copper. Soil Sci. Soc of Amer. J. 42: 421-428.

Mandal, S. 2018. Characterization and Delineation of Farming Situations of Chhattisgarh Plains, M. Tech. (Agril.Engg.) Thesis, I.G.K.V. Raipur (Chhattisgarh): 34-50.

Motghare, R., Meher, S. K., Motghare, H.,
Banwasi, R. and Sahu, K. K. 2020. Evaluation of Soil Fertility Status and its Variation in Arang Block of Raipur District in Chhattisgarh. Int. J. Curr. Microbio. App. Sci., 10: 461-469.

Olsen, S. R., Watanabe F. S., C. V. Cole, \& L. A. Dean. 1954. Estimation of Available P in Soils by Extraction with Sodium Bicarbonate. U.S.D.A. Circular No. 939.

Piper, C. S. 1967. Soil and plant analysis. Asian publishing House, Bombay, New Delhi. 85-102.

Rakesh, K., Rakesh, K. U. S. and Brijesh, Y. 2012. Vertical distribution of physicochemical properties under different toposequence in soils of Jharkhand. Journal of Agricultural Physics, 12(1):63- 69.

Sathish, A., Ramachandrappa, B. K., Devaraja, K., Savitha, M. S., Gowda, M. N. T. and Prashanth, K. M. 2018. Assessment of spatial variability in fertility status and nutrient recommendation in alanatha Cluster Villages, Ramanagara District, Karnataka using GIS. Journal of The Indian Society of Soil Science, 66(2):149.

Subbiah, V. \& Asija, G. L. 1956. A rapid procedure for estimation of available nitrogen in soil Current Science 25:259260.

Vaisnow, B., 2010. Evaluation of Soil Fertility Status in Vertisol of Dhamtari Block, under Dhamtari District in Chhattisgarh, M. Sc. (Ag.) Thesis, I.G.K.V. Raipur (Chhattisgarh): 49-115.

Vishal, D. J., Narahari, N. P. and Punit, R. R. 2009. Physico-chemical properties of four farm site soils in area surrounding Rajkot, Gujarat, India. International Journal of Chemical Technical Research, 1(3): 709-713.

Williams, C. \& Steinbergs, A. (1969). The evaluation of plant-available sulphur in soils. Plant and Soil, 17(3): 279-294. 


\section{How to cite this article:}

Amit Singh Sengar, K. Tedia, D. Khalkho, Gourav Jatav, Manoj Kumar Tarar and Ravishankar Dadsena. 2021. Macro and Micro Nutrient Status of Instructional Farm, College of Agriculture and Research Station Raipur, District Raipur, Chhattisgarh. Int.J.Curr.Microbiol.App.Sci. 10(12): 198-205. doi: https://doi.org/10.20546/ijcmas.2021.1012.023 